This Accepted Author Manuscript is copyrighted and published by Elsevier. It is posted here by agreement between Elsevier and University of Brasilia. Changes resulting from the publishing process - such as editing, corrections, structural formatting, and other quality control mechanisms - may not be reflected in this version of the text. The definitive version of the text was subsequently published in [Theriogenology, Volume 62, Issues 1-2, July 2004, Pages 65-80, doi:10.1016/j.theriogenology.2003.07.025].You may download, copy and otherwise use the AAM for non-commercial purposes provided that your license is limited by the following restrictions:

(1) You may use this AAM for non-commercial purposes only under the terms of the CC-BY-NCND license.

(2) The integrity of the work and identification of the author, copyright owner, and publisher must be preserved in any copy.

(3) You must attribute this AAM in the following format: [agreed attribution language, including link to CC BY-NC-ND license + Digital Object Identifier link to the published journal article on Elsevier's ScienceDirect ${ }^{\circledR}$ platform].

Este Manuscrito do Autor Aceito para Publicação (AAM) é protegido por direitos autorais e publicado pela Elsevier. Ele esta disponível neste Repositório, por acordo entre a Elsevier e a Universidade de Brasília. As alterações decorrentes do processo de publicação - como a edição, correção, formatação estrutural, e outros mecanismos de controle de qualidade - não estão refletidas nesta versão do texto. A versão definitiva do texto foi posteriormente publicado em [Theriogenology, Volume 62, Número 1-2, Julho de 2004, Páginas 65-80, doi:10.1016/j.theriogenology.2003.07.025]. Você pode baixar, copiar e utilizar de outra forma o AAM para fins não comerciais, desde que sua licença seja limitada pelas seguintes restrições:

(1) Você pode usar este AAM para fins não comerciais apenas sob os termos da licença CC- BYNC-ND.

(2) A integridade do trabalho e identificação do autor, detentor dos direitos autorais e editor deve ser preservado em qualquer cópia.

(3) Tem de atribuir este AAM no seguinte formato: [acordo na linguagem atribuída, incluindo o link para CC BY-NC-ND licença Digital + DOI do artigo publicado na revista Elsevier ScienceDirect ${ }^{\circledR}$ da plataforma]. 


\section{Morphological and ultrastructural analysis of sheep primordial follicles preserved in 0.9\% saline solution and TCM 199}

M.H.T Matos

E.R Andrade

C.M Lucci

S.N Báo

J.R.V Silva

R.R Santos

M.A.L Ferreira

S.H.F Costa

J.J.H Celestino

J.R Figueiredo

\section{Abstract}

The objective was to determine the morphological and ultrastructural features of sheep primordial follicles preserved in either $0.9 \%$ saline solution or TCM 199 at different temperatures. Soon after death, the ovarian pair of each ewe $(n=5)$ was divided into 25 fragments. One fragment was immediately fixed for morphological evaluation (control). The other 24 fragments were randomly distributed in tubes containing $2 \mathrm{ml}$ of $0.9 \%$ saline solution or TCM 199 and maintained at 4,20 or $39{ }^{\circ} \mathrm{C}$ for $2,4,12$, or $24 \mathrm{~h}$. Based on histological assessment, storage of ovarian fragments in $0.9 \%$ saline solution at $20^{\circ} \mathrm{C}$ for up to $24 \mathrm{~h}$ and in both solutions at $39{ }^{\circ} \mathrm{C}$ for 4,12 or $24 \mathrm{~h}$ increased $(\mathrm{P}<0.01)$ the percentage of degenerate primordial follicles compared with controls. In contrast, preservation at $4{ }^{\circ} \mathrm{C}$ in both solutions, kept the percentage of morphologically normal primordial follicles similar to control values. Although histological integrity of primordial follicles was maintained in fragments stored at 20 ${ }^{\circ} \mathrm{C}$ for up to $24 \mathrm{~h}$ in TCM 199, these results were not confirmed by ultrastructural analysis. Based on transmission electron microscopy, only primordial follicles stored at $4{ }^{\circ} \mathrm{C}$ for up to 24 $\mathrm{h}$, at $20^{\circ} \mathrm{C}$ for up to $12 \mathrm{~h}$ and at $39{ }^{\circ} \mathrm{C}$ for up to $2 \mathrm{~h}$ in both solutions were ultrastructurally normal. In conclusion, sheep primordial follicles were successfully preserved at $4{ }^{\circ} \mathrm{C}$ for up to $24 \mathrm{~h}$, at $20^{\circ} \mathrm{C}$ for up to $12 \mathrm{~h}$ and at $39^{\circ} \mathrm{C}$ for $2 \mathrm{~h}$ in $0.9 \%$ saline solution or TCM 199.

Keywords: Sheep; Primordial follicle; Preservation; Morphology; Ultrastructural

\section{Introduction}

The mammalian ovary contains a follicular reserve that is determined before birth and cannot be replenished. This reserve contains thousands of primordial follicles, corresponding to $95 \%$ of the preantral follicle population [1]. Since the vast majority of primordial follicles become atretic during growth and maturation in vivo, these follicles provide a valuable source for studies on in vitro development of oocytes and in vitro production of embryos [2]. Biotechnologies developed for isolation [3], [4] and [5], cryopreservation [6] and culture [7] of 
preantral follicles strive to prevent follicular atresia by rescuing preantral follicles from ovaries and by maturing these follicles during in vitro culture.

Since oocytes enclosed in primordial follicles are small and less metabolically active, they may be more tolerant to the preservation process than metaphase II oocytes [8]. Preservation of primordial follicles requires not only the survival of oocyte and granulosa cells, but also maintenance of gap junctions and metabolic cooperation that are essential for oocyte growth and development [9]. In addition, maintenance of follicular quality after preservation is extremely important and should be investigated, because structural or ultrastructural damages can significantly affect further in vitro growth and maturation of oocytes within primordial follicles [10]. Some authors have emphasized the importance of ultrastructural evaluation after in vitro preservation of preantral follicles, since histologically normal follicles may have degenerative changes detected only with electron microscopy [11] and [12].

Recently, some studies have demonstrated that the quality of the oocytes enclosed in preantral follicles depends on the preservation medium, temperature and incubation time during ovary transportation from the field to the laboratory. Saline solution (0.9\%) is largely cited as a short-duration preservation medium for ovaries (cattle [13]; goat [14]) and for preservation of goat [12] and sheep [15] preantral follicles in situ. However, TCM 199 has been successfully used in the preservation of goat [16] and sheep [17] preantral follicles. Carvalho et al. [12] showed that after preservation in Braun-Collins and $0.9 \%$ saline solutions, the degeneration rate of goat secondary follicles was higher than that observed in primordial follicles. However, studies performed in sheep indicated only the overall incidence of follicular degeneration after preservation, considering all classes of preantral follicles (primordial, primary and secondary follicles). In these studies, a high rate of follicular degeneration was observed after storage at $39{ }^{\circ} \mathrm{C}$ for all incubation periods (even for $4 \mathrm{~h}$ ). On the other hand, the effect of $0.9 \%$ saline solution and TCM 199 for a shorter incubation period (e.g. 2 h), was not investigated. In addition, ultrastructural analysis of sheep primordial follicles preserved in vitro has not been reported.

The objectives of the present study were to evaluate the effect of $0.9 \%$ saline solution and TCM 199 on the preservation of sheep primordial follicles, at different temperatures and incubation times, and to investigate the histologic and ultrastructural morphology of the preserved primordial follicles. 


\section{Materials and methods}

\subsection{Source of ovaries}

Ovaries $(n=10)$ from five adult non-pregnant mixed-breed ewes were collected at a local abbatoir. The animals were cycling and in good body condition. Under aseptic conditions, the ovaries were stripped of surrounding fat tissue and ligaments, washed once in a $70 \%$ alcohol solution, and then twice in $0.9 \%$ saline solution.

\subsection{Media}

The media used were: (1) sterile $0.9 \%$ saline solution $(0.9 \% \mathrm{NaCl}$; osmolarity 300 mOsmol/l; pH 7.2) and (2) TCM 199 (osmolarity 280 mOsmol/l; pH7.2; Cultilab, SP, Brazil).

\subsection{Experimental protocol}

At the abbatoir, the pair of ovaries from each animal was divided into 25 fragments ( 25 pieces from both ovaries combined). For control purposes (control, treatment 1, time 0), a small piece of a randomly selected ovarian fragment was removed for transmission electron microscopy (TEM) with the remainder immediately fixed in Carnoy for histological examination. The other 24 fragments were randomly distributed into $15 \mathrm{ml}$ tubes (Corning Glass Works, Corning, NY, USA) containing $2 \mathrm{ml}$ of $0.9 \%$ saline solution or TCM 199 at 4, 20 or $39{ }^{\circ} \mathrm{C}$ and stored for 2, 4, 12, or $24 \mathrm{~h}$ (treatments 2-25) as shown in Fig. 1. The temperatures were maintained using thermoflasks filled with water at 4,20 or $39{ }^{\circ} \mathrm{C}$ and were monitored at the beginning and at the end of the treatments. Each treatment was repeated five times. 


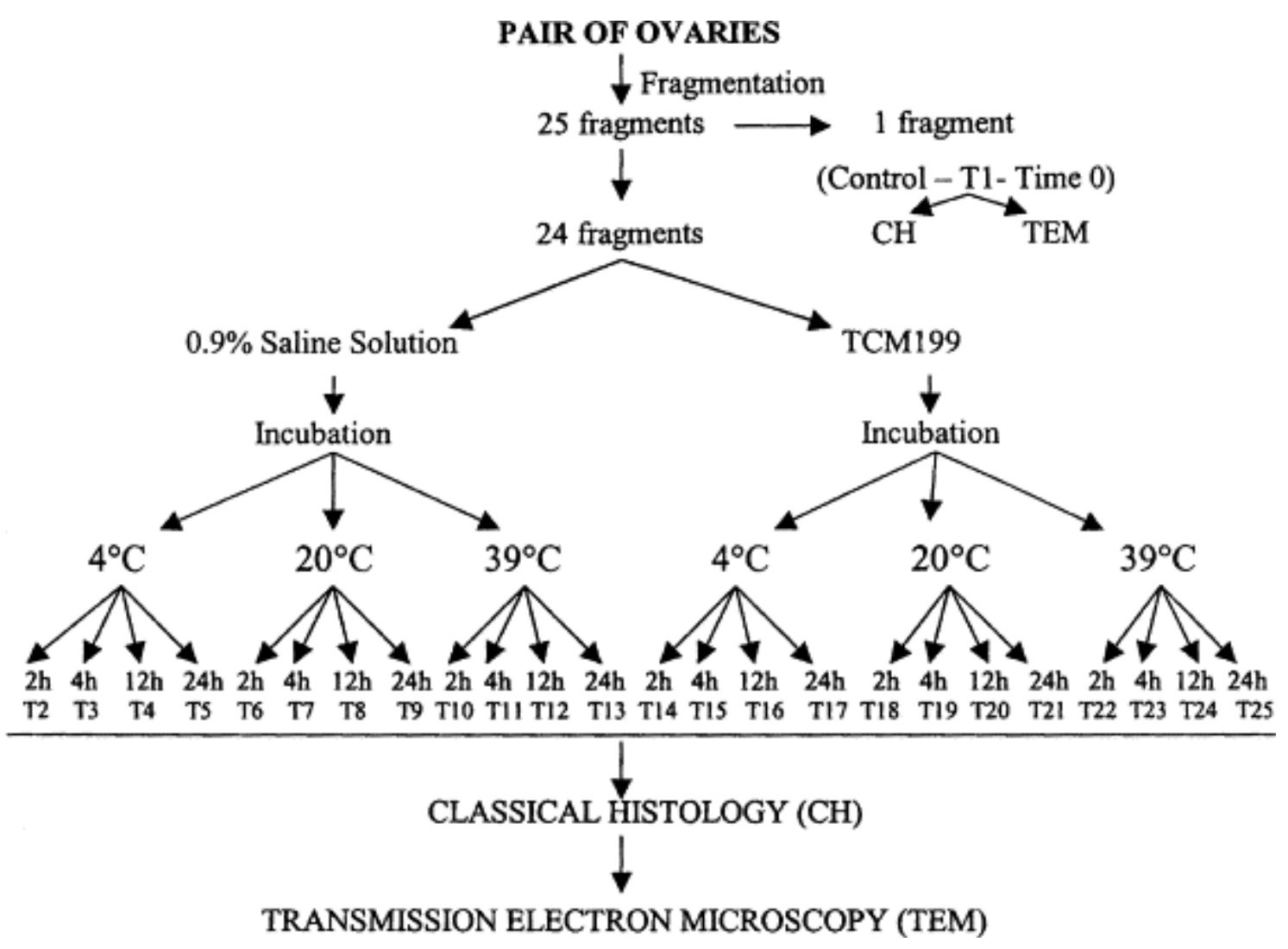

Fig. 1. General experimental protocol for preservation of ovine primordial follicles.

\subsection{Light microscopy}

To evaluate the morphology of ovine primordial follicles, at the end of each treatment, ovarian fragments were processed as follows. Following the removal of a small piece from each fragment for TEM, the remainder was fixed individually in Carnoy for $12 \mathrm{~h}$. Then, they were dehydrated in a graded series of ethanol, clarified with xylene and embedded in paraffin wax. Sections $7 \mu \mathrm{m}$ thick were stained by a standard protocol using periodic acid schiff (PAS)hematoxilyn and examined by light microscopy (Zeiss, Germany) under 400x magnification. To avoid counting a follicle more than once, a primordial follicles was counted only in a sections where the oocyte nucleus was visible.

Follicular morphology was evaluated based on the integrity of the basement membrane, cellular density, presence or absence of pycnotic bodies, and oocyte integrity. Based on these variables, primordial follicles were classified as morphologically normal (follicles had a healthy spherical oocyte with uniform cytoplasm, and granulosa cells, well-organized in layers, without pycnotic nuclei, were observed surrounding the oocyte); Type 1 degenerate follicles (follicles had an oocyte that was sometimes retracted, with a pycnotic nucleus and wellorganized granulosa cells without pycnotic nucleus) or Type 2 degenerate follicles 
(degeneration of both oocyte and granulosa cells; follicles had a retracted oocyte, with or without a pycnotic nucleus, and disorganized low-density, swollen granulosa cells) (Fig. 2).

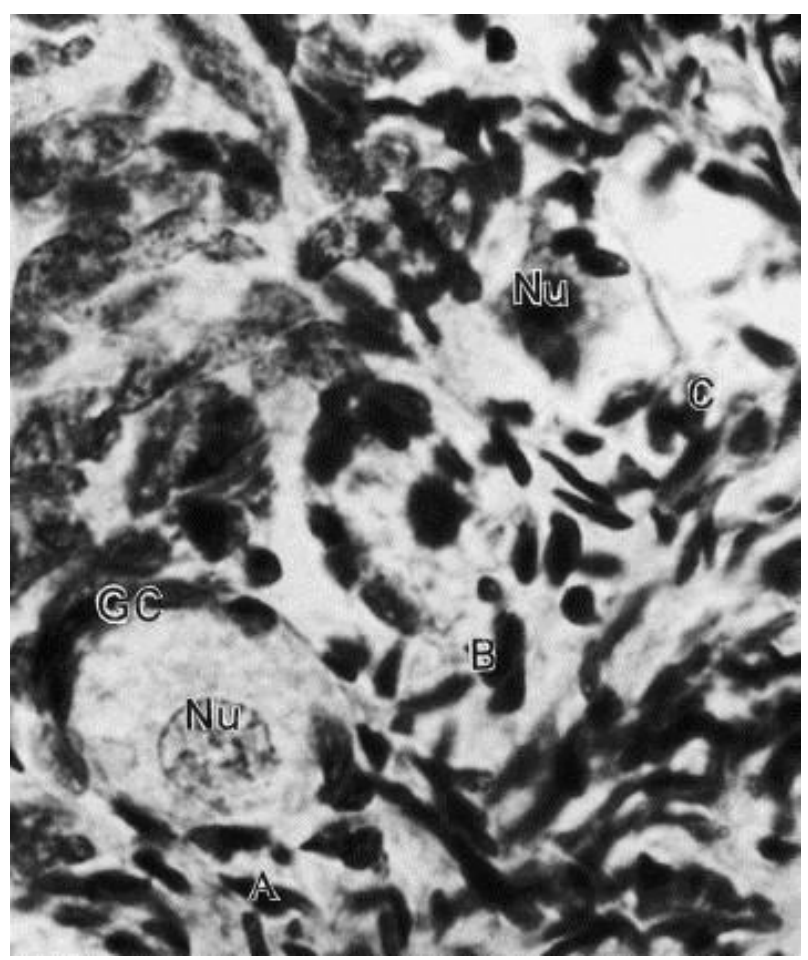

Fig. 2. Histological section of a sheep ovarian fragment, showing normal (A), degenerate Type 1 (B), degenerate Type 2 (C) primordial follicles. GC: granulosa cells, Nu: oocyte nucleus. PAS-hematoxilin stained (400x).

\subsection{Transmission electron microscopy}

To better evaluate follicular morphology, ultrastructural analysis was performed on primordial follicles from the control treatment, as well as on treatments that did not differ from control. Only primordial follicles classified as morphologically normal in semi-thin sections were evaluated. Briefly, small pieces of ovarian cortex were fixed in a solution containing $2 \%$ paraformaldehyde and $2.5 \%$ glutaraldehyde in $0.1 \mathrm{M}$ sodium cacodylate buffer $(\mathrm{pH}$ 7.2). After fixation, specimens were rinsed in buffer and post-fixed in $1 \%$ osmium tetroxide, $0.8 \%$ potassium ferricyanide and $5 \mathrm{mM} \mathrm{CaCl} 2$ in $0.1 \mathrm{M}$ sodium cacodylate buffer. Subsequently, samples were dehydrated in acetone and embedded in Spurr's epoxy resin. Thin sections $(80 \mathrm{~nm})$ were prepared when the oocyte nucleus was present in the semi-thin sections. Semi-thin sections ( $3 \mu \mathrm{m})$ were stained with toluidine blue, while thin sections were contrasted with uranyl acetate and lead citrate, and examined using a Jeol $100 \mathrm{C}$ (Jeol, Tokyo, Japan) transmission electron microscope. 


\subsection{Statistical analysis}

The GLM procedure of the SAS (SAS, Inc., Cary, NC, USA) was used for the analysis of variance (ANOVA) of data. The factors used in the model for analysis of normal and degenerate primordial follicles included medium $(0.9 \%$ saline solution, $\operatorname{TCM})$, temperature $\left(4,20\right.$ or $\left.39^{\circ} \mathrm{C}\right)$, incubation time $(2,4,12$, or $24 \mathrm{~h})$ and interactions. Differences between the control and other treatments were performed by Fisher's PLSD-test. Before statistical analysis, frequency of follicular types was transformed to arcsin. Values were considered statistically significant when $\mathrm{P}<0.05$.

\section{Results}

\subsection{Storage of sheep primordial follicles in situ in $0.9 \%$ saline solution or in TCM 199}

A total of 3638 primordial follicles were examined histologically. The number of follicles ranged from 115 to 152 in each treatment. There was an effect of medium $(P<0.05)$, temperature $(P<0.01)$ and incubation time $(P<0.01)$, as well as an interaction between temperature and incubation time $(P<0.01)$.

The effect of temperature and storage time on the percentage of morphologically normal primordial follides (MNPF) stored in 0.9\% saline solution or in TCM 199 is shown in Fig. 3. The percentage of normal follicles stored in $0.9 \%$ saline solution at $4{ }^{\circ} \mathrm{C}$ for up to $24 \mathrm{~h}$, at 20 ${ }^{\circ} \mathrm{C}$ for $12 \mathrm{~h}$ and at $39{ }^{\circ} \mathrm{C}$ for $2 \mathrm{~h}$ was similar $(\mathrm{P}>0.01)$ to control (time zero). A decrease $(\mathrm{P}<0.01)$ in the number of MNPF was observed when primordial follicles were stored in saline solution at $20^{\circ} \mathrm{C}$ for $24 \mathrm{~h}$ and at $39^{\circ} \mathrm{C}$ for 4,12 or $24 \mathrm{~h}$ when compared to control. Similar results were obtained when TCM 199 was used, except for the treatment in which the ovarian fragment was stored at $20^{\circ} \mathrm{C}$ for $24 \mathrm{~h}$; in this treatment, the percentage of MNPF was similar $(P>0.01)$ to control. 


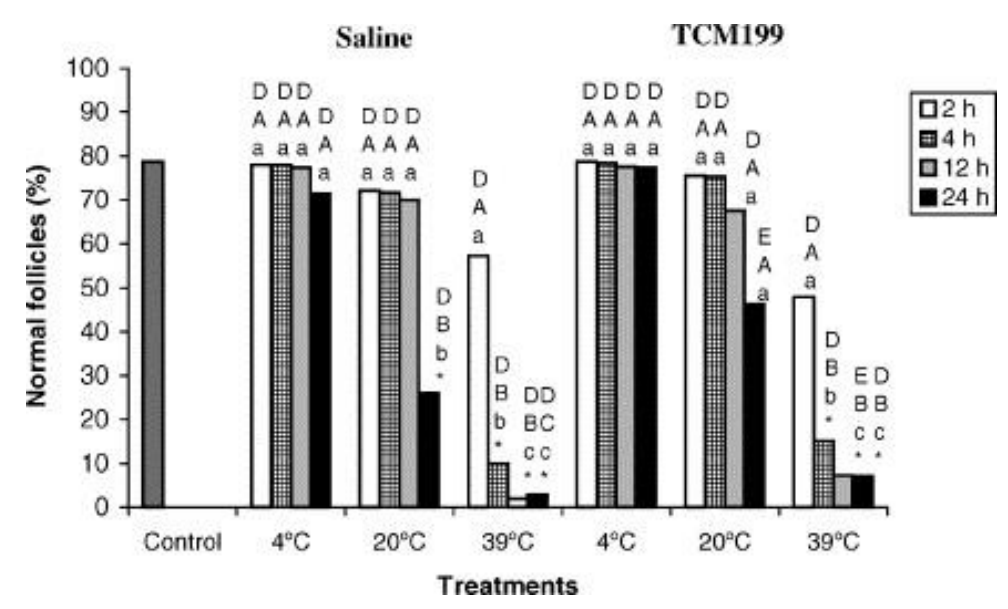

Fig. 3. Effect of temperature and storage time on the percentage of morphologically normal primordial follicles preserved in saline solution $0.9 \%$ and in TCM 199. (*) Differ from control $(P<0.01) ;(a, b, c)$ different letters at the same preservation temperature differ $(P<0.01) ;(A, B, C)$ different letters in the same preservation period differ $(P<0.01) ;(D, E)$ different letters among the solution in the same preservation period and temperature differ $(\mathrm{P}<0.05)$.

The effect of incubation time within each temperature was analyzed, separately, in each solution. At $4{ }^{\circ} \mathrm{C}$ the percentage of MNPF was not affected by the incubation time, in both solutions. Similar results were obtained in fragments preserved in TCM 199 at $20^{\circ} \mathrm{C}$. However, in the fragments stored at $20{ }^{\circ} \mathrm{C}$ in $0.9 \%$ saline solution, there was a decrease $(P<0.01)$ in the percentage of MNPF when stored for $24 \mathrm{~h}$ compared to 2,4 or $12 \mathrm{~h}$. A decrease $(\mathrm{P}<0.01)$ in the number of MNPF occurred with the increase of incubation time from 2 to $4 \mathrm{~h}, 12$ and $24 \mathrm{~h}$, in both solutions at $39^{\circ} \mathrm{C}$.

With respect to the effect of temperature for the same period of incubation, there was a decrease $(P<0.01)$ in the percentage of MNPF in both solutions at all incubation periods tested when the fragments were stored at $39{ }^{\circ} \mathrm{C}$, when compared to 4 and $20{ }^{\circ} \mathrm{C}$. However, fragments stored for $2 \mathrm{~h}$ at $39{ }^{\circ} \mathrm{C}$ did similar follicular viability when compared with storage at 4 and $20^{\circ} \mathrm{C}$.

The comparison between $0.9 \%$ saline solution and TCM 199 at the same temperature and incubation period showed that the percentage of MNPF at $4{ }^{\circ} \mathrm{C}$ in all incubation periods tested was not different $(P>0.05)$. However, a higher $(P<0.05)$ percentage of MNPF was observed in TCM 199 at $20^{\circ} \mathrm{C}$ for $24 \mathrm{~h}$ and at $39^{\circ} \mathrm{C}$ for $12 \mathrm{~h}$.

\subsection{Distribution of follicular degeneration types in control and other treatments}

Fig. 4 shows the distribution of Types 1 and 2 degenerate primordial follicles, in control and after storage in the different treatments, in 0.9\% saline solution (Fig. 4a) and in TCM 199 (Fig. 4b). A predominance $(P<0.01)$ of degenerate Type 1 follicles was observed in control and 
after storage in $0.9 \%$ saline solution at $4{ }^{\circ} \mathrm{C}$ for 4,12 and $24 \mathrm{~h}$, at $20^{\circ} \mathrm{C}$ for $12 \mathrm{~h}$, and in TCM 199 at $4{ }^{\circ} \mathrm{C}$ for $12 \mathrm{~h}$ and at $20^{\circ} \mathrm{C}$ for 2 and $4 \mathrm{~h}$. In contrast, an increase $(P<0.01)$ of degenerate Type 2 follicles was observed after storage in both solutions at $39{ }^{\circ} \mathrm{C}$ at all incubation times, except in the fragments stored in saline solution $0.9 \%$ for $2 \mathrm{~h}$. Compared to control, a higher $(\mathrm{P}<0.01)$ percentage of Type 1 degenerate follicles was observed in $0.9 \%$ saline solution at 4 and $20^{\circ} \mathrm{C}$ for 12 and $24 \mathrm{~h}$ and at $39{ }^{\circ} \mathrm{C}$ for $4 \mathrm{~h}$. A greater $(\mathrm{P}<0.01)$ percentage of degenerate Type 2 follicles compared to control was observed in follicles preserved in $0.9 \%$ saline solution at $4{ }^{\circ} \mathrm{C}$ for 2 and $24 \mathrm{~h}$, at $20^{\circ} \mathrm{C}$ for 2,4 and $24 \mathrm{~h}$, at $39^{\circ} \mathrm{C}$ for 4,12 and $24 \mathrm{~h}$, and in TCM 199 at $20^{\circ} \mathrm{C}$ for $24 \mathrm{~h}$ and at $39^{\circ} \mathrm{C}$ at all incubation periods.
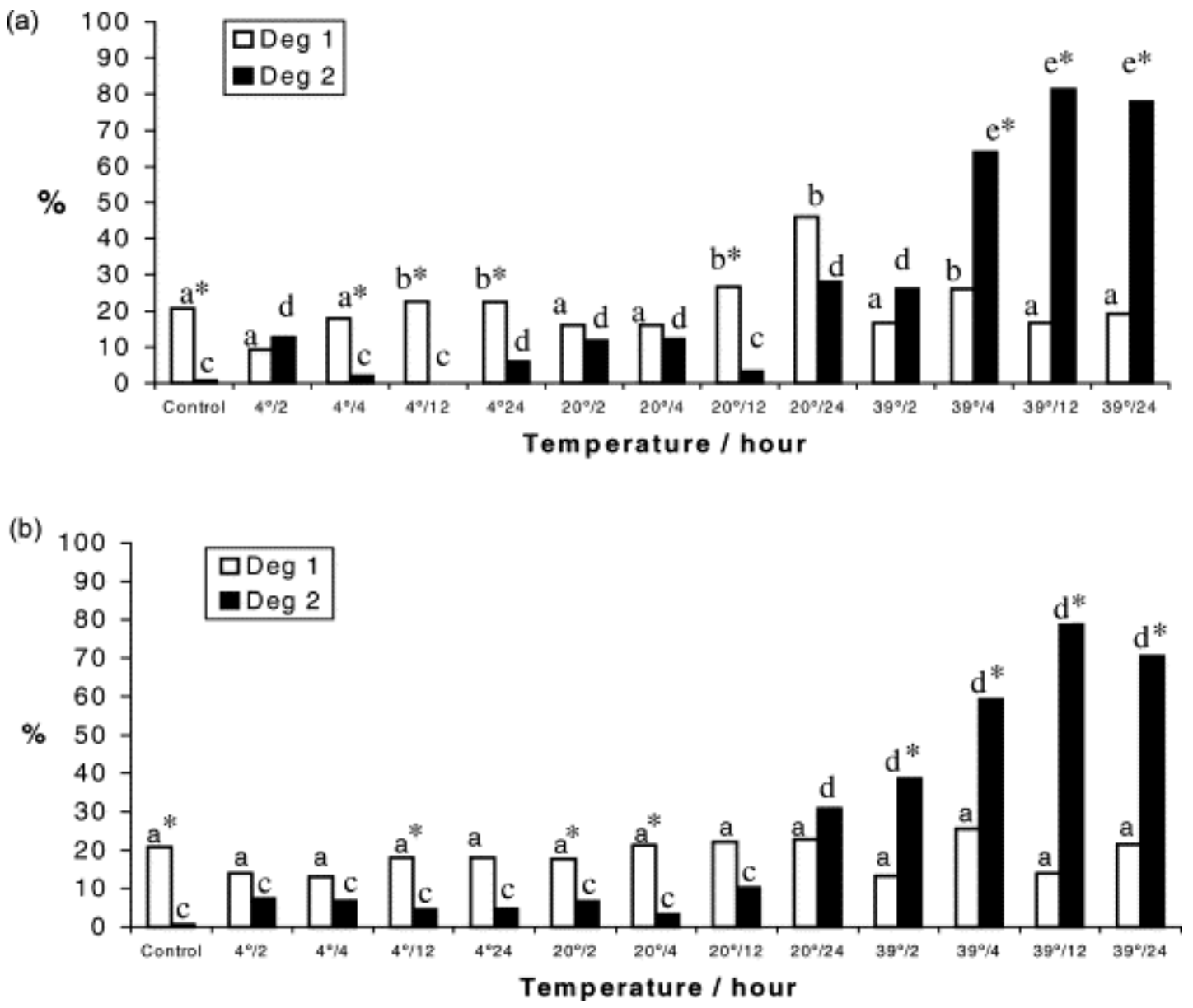

Fig. 4. Percentage distribution of Type 1 (Deg 1) and Type 2 (Deg 2) degenerate primordial follicles from control and after conservation in different treatments, in 0.9\% saline solution (a) and in TCM 199 (b). (*) Difference $(P<0.01)$ in degeneration types within each treatment; $(a, b)$ different letters indicate difference $(P<0.01)$ in the percentage of Type 1 degenerate follicles found in different treatments and control; $(c, d, e)$ different letters indicate difference $(P<0.01)$ in the percentage of Type 2 degenerate follicles found in different treatments and control. 


\subsection{Ultrastructural analysis of sheep primordial follicles in control and after preservation}

On average, eight primordial follicles per treatment were evaluated by ultrastructural analysis. Normal primordial follicles exhibited a highly variable number of vesicles spread throughout the ooplasm. The cytoplasm also contained numerous large pleiomorphic mitochondria, with irregular cristae and continuous mitochondrial membranes, including elongated forms with parallel cristae. Well-developed Golgi complexes were observed. Both smooth and rough endoplasmic reticulum were present, either as isolated aggregations or as complex associations with mitochondria and vesicles. In normal primordial follicles, there were sometimes a few microvilli and, occasionally, small amounts of zona pellucida material were visible, depending on the plane of section. Granulosa cells had irregularly-shaped nuclei, with a high nucleus-to-cytoplasm ratio. The cytoplasm contained a great number of mitochondria and well-developed rough endoplasmic reticulum. These features were observed in primordial follicles from control group (Fig. 5), as well as in follicles preserved in $0.9 \%$ saline solution and in TCM 199 at $4{ }^{\circ} \mathrm{C}$ for up to $24 \mathrm{~h}$ (Fig. 6), at $20^{\circ} \mathrm{C}$ for up to $12 \mathrm{~h}$ (Fig. 7), and at $39^{\circ} \mathrm{C}$ for up to 2 h (Fig. 8; control).

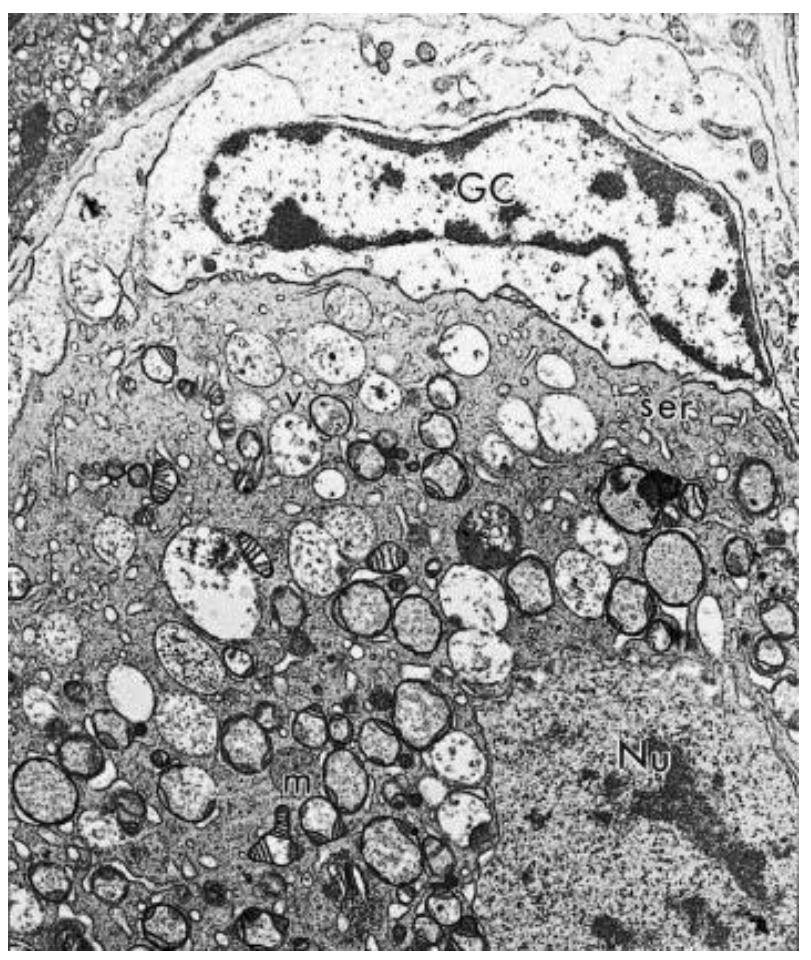

Fig. 5. Electron micrograph of a follicle from control group. GC: granulosa cells, Nu: oocyte nucleus, m: mitochondria, ser: smooth endoplasmic reticulum, v: vesicles. (3700x). 


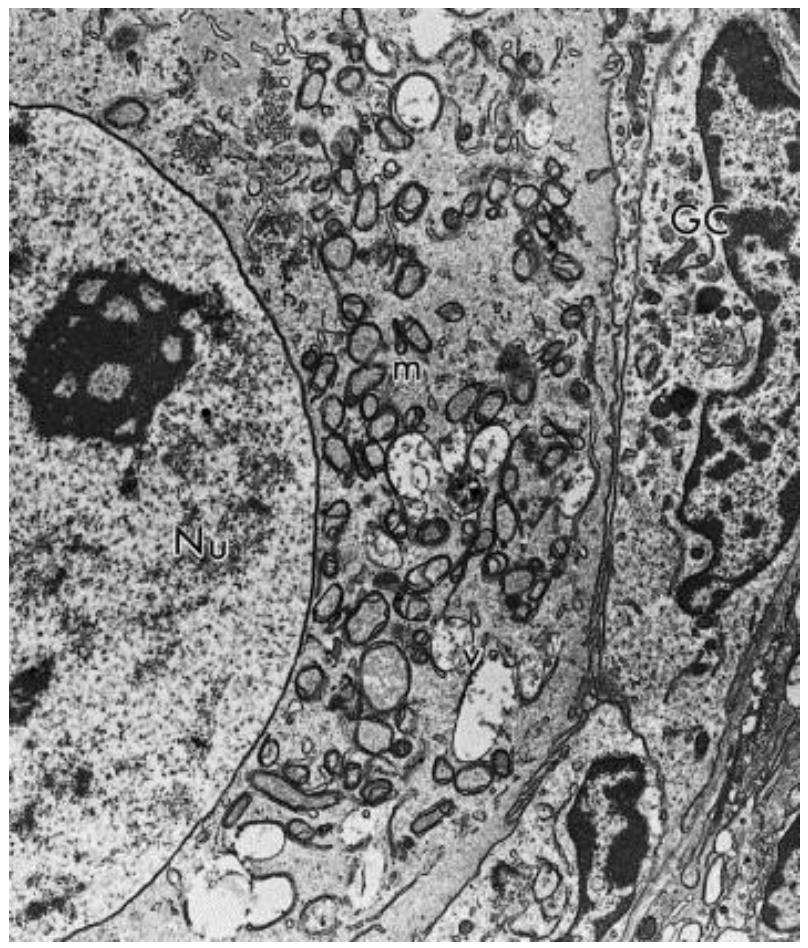

Fig. 6. Electron micrograph of a follicle preserved in $0.9 \%$ saline solution at $4{ }^{\circ} \mathrm{C}$ for $24 \mathrm{~h}$. GC: granulosa cells, Nu: oocyte nucleus, m: mitochondria, v: vesicles (3700x).

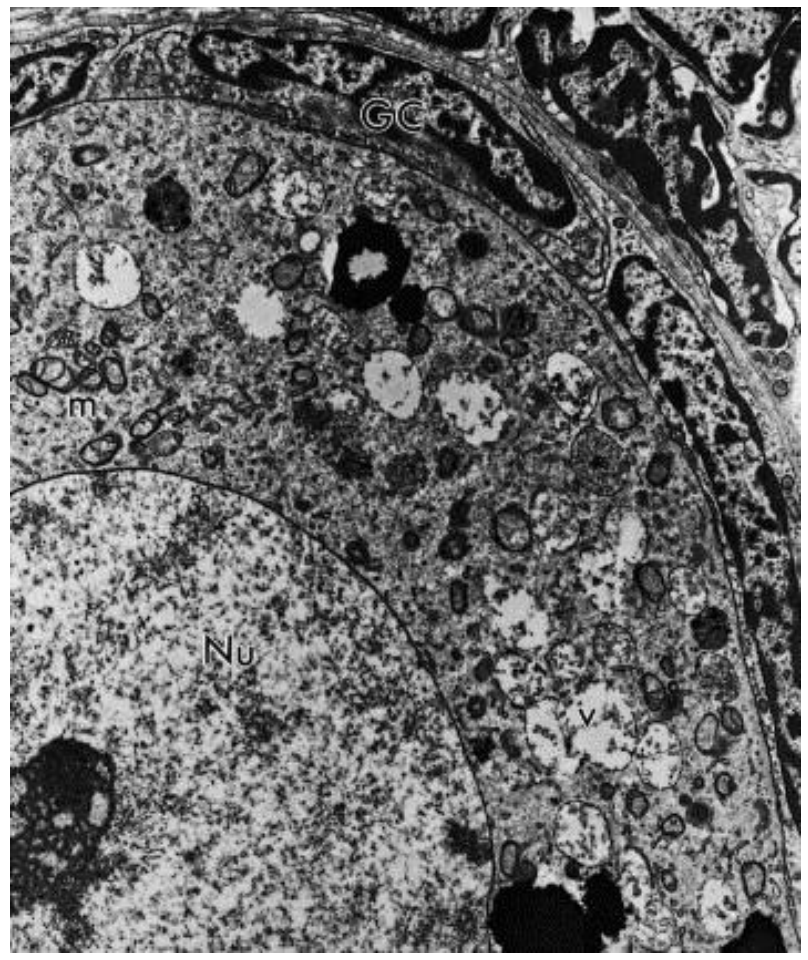

Fig. 7. Electron micrograph of a follicle preserved in $0.9 \%$ saline solution at $20^{\circ} \mathrm{C}$ for $12 \mathrm{~h}$. GC: granulosa cells, Nu: oocyte nucleus, m: mitochondria, v: vesicles (3700x). 


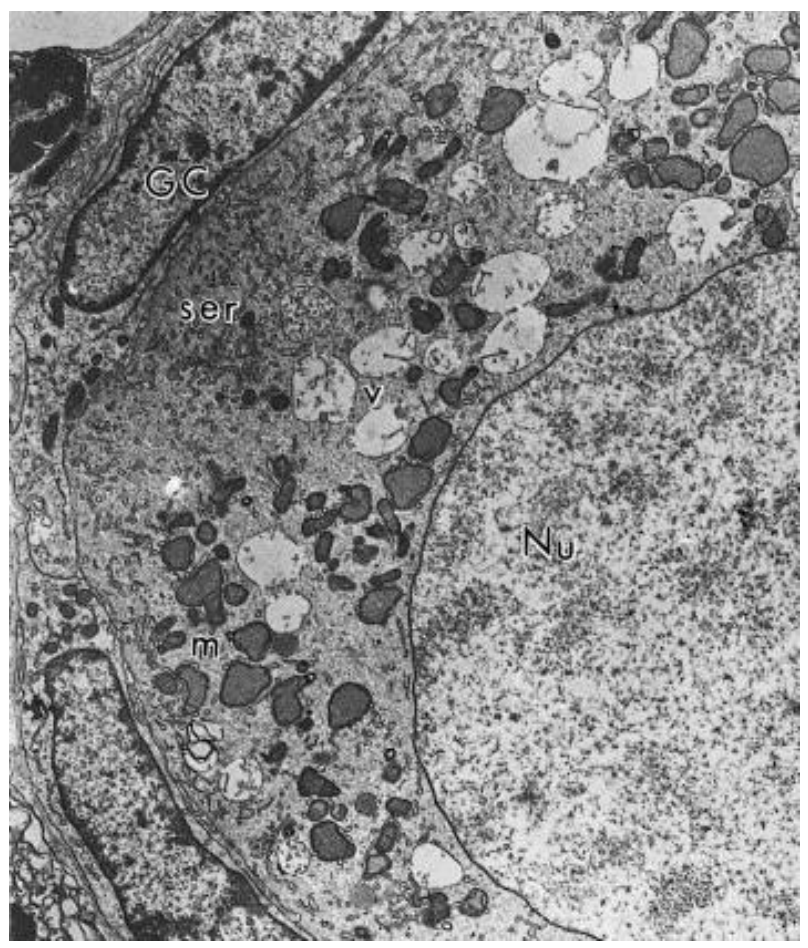

Fig. 8. Electron micrograph of a follicle preserved in TCM 199 at $39{ }^{\circ} \mathrm{C}$ for $2 \mathrm{~h}$. GC: granulosa cells, Nu: oocyte nucleus, m: mitochondria, ser: smooth endoplasmic reticulum, v: vesicles (3700x).

When stored in TCM 199 at $20^{\circ} \mathrm{C}$ for $24 \mathrm{~h}$, follicles seemed to be well preserved in semi-thin sections stained with toluidine blue, however, transmission electron microscopy revealed some discreet changes in their ultrastructure (Fig. 9). In primordial follicles, oocytes had signs of degeneration before the primitive granulosa cells. The ooplasm of these follicles was extremely vacated, with the vacuoles often fusing to produce a greater vacated area. In addition, initial signs of damage to mitochondrial membranes and cristae were observed. Granulosa cells were slightly swollen, with a low density of organelles present in their cytoplasm. Some granulosa cells disappeared, leaving a vacated space. The follicles contained a retracted oocyte and substantial irregularity of the follicular, oocyte and nuclear outlines (Fig. 9). However, ultrastructural analysis of primordial follicles stored in TCM 199 at $20^{\circ} \mathrm{C}$ for up to $12 \mathrm{~h}$ confirmed the integrity of the oocyte, the granulosa cells, and the basement membrane (Fig. 10), consistent with the results obtained histologically. 


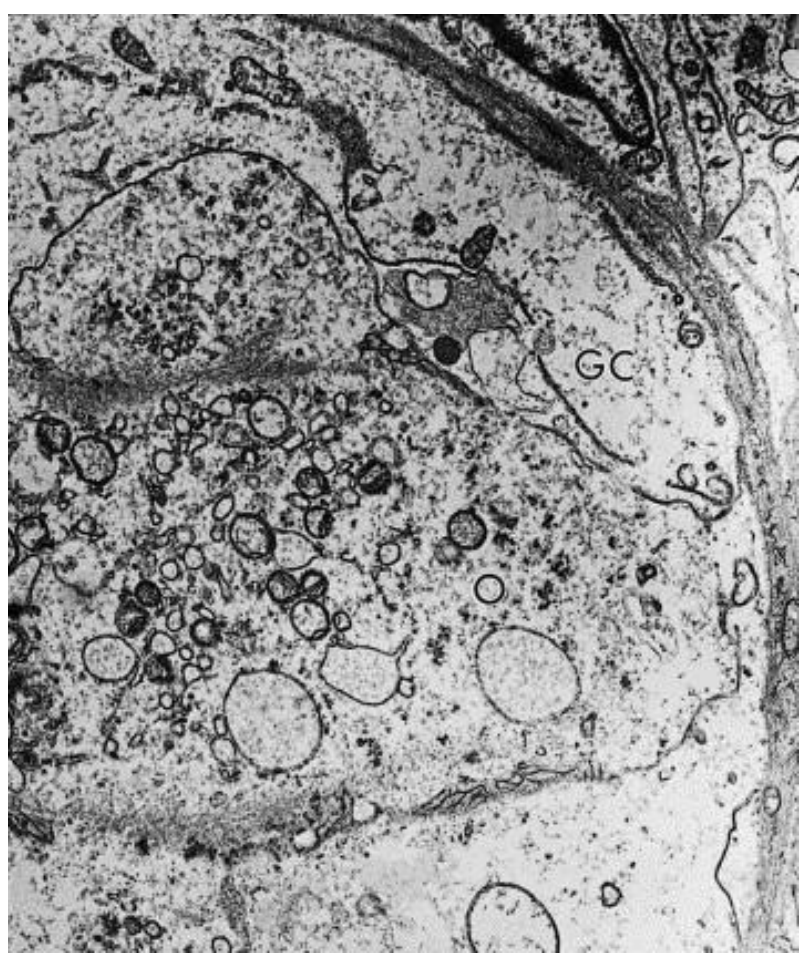

Fig. 9. Electron micrograph of a follicle preserved in TCM 199 at $20{ }^{\circ} \mathrm{C}$ for $24 \mathrm{~h}$. Note the degenerate appearance of the oocyte and granulosa cells. O: oocyte, GC: granulosa cells $(4600 x)$.

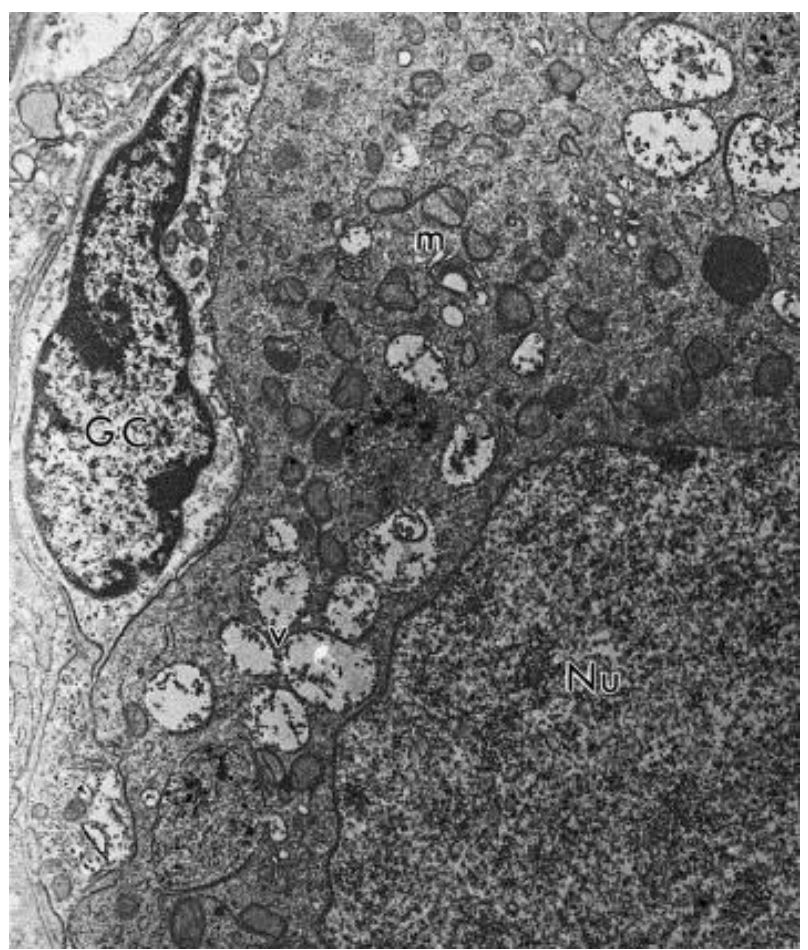

Fig. 10. Electron micrograph of a follicle preserved in TCM 199 at $20^{\circ} \mathrm{C}$ for $12 \mathrm{~h}$. GC: granulosa cells, Nu: oocyte nucleus, m: mitochondria, v: vesicles (4600×). 


\section{Discussion}

In the present study, the storage of ovarian fragments in $0.9 \%$ saline solution and in TCM 199 at $4{ }^{\circ} \mathrm{C}$ sustained the number of morphologically normal primordial follicles compared to control (time zero). In contrast, preservation in either media at 20 or $39{ }^{\circ} \mathrm{C}$, depending on the incubation period, increased the degeneration rate of sheep primordial follicles in vitro.

Preservation of ovarian fragments at $4{ }^{\circ} \mathrm{C}$ for up to $24 \mathrm{~h}$, in either solution, maintained the percentage of normal primordial follicles similar to that found in control. Although studies available did not specifically evaluate the effect of media and temperature on the preservation of primordial follicles (they usually considered all classes of preantral follicles together), they demonstrated that a temperature of $4{ }^{\circ} \mathrm{C}$ has been successfully used in the follicular preservation for $24 \mathrm{~h}$ in solutions poor (saline [12] and [15]) and rich (TCM 199 [17]) in nutrients or hyperosmotic (Braun-Collins solution [18]). Therefore, at $4{ }^{\circ} \mathrm{C}$ the composition of the medium is not a limiting factor. In addition, Wood et al. [19] successfully preserved domestic cat ovarian follicles at $4{ }^{\circ} \mathrm{C}$ for $48 \mathrm{~h}$. Moreover, Jewgenow et al. [6] cooled isolated feline preantral follicles at $4{ }^{\circ} \mathrm{C}$ without decreasing the percentage of healthy follicles. Roy and Treacy [20] observed that a lower metabolic rate at low temperatures may be beneficial for maintaining viable human preantral follicles in vitro after isolation; preservation at low temperatures $\left(4^{\circ} \mathrm{C}\right)$ can minimize metabolic requirements and increase follicular resistance to reduced nutrients and oxygen. Pickering et al. [21] showed that the meiotic spindle of oocytes was temperature-sensitive during cooling. However, the quality of primordial follicles was not evaluated. Oocytes enclosed in primordial follicles may be less susceptible to microtubular disruptions, because most of the microtubular systems remain unorganized, and the chromatin is in a condensed form protected by the nuclear membrane [22]. In spite of the good results obtained in this study (as well as in others) in preservation of primordial follicles at $4{ }^{\circ} \mathrm{C}$, it is unknown if the temperature reduction could affect the culture of primordial follicles in vitro.

In the present study, when primordial follicles were stored at $20^{\circ} \mathrm{C}$ for 12 and $24 \mathrm{~h}$ in $0.9 \%$ saline solution and in TCM 199 , respectively, and at $39{ }^{\circ} \mathrm{C}$ for $2 \mathrm{~h}$ in both solutions, the percentage of normal primordial follicles was not significantly different from control. Similar results were observed with the preservation of preantral follicles (without specific follicular type) at 20 and $39{ }^{\circ} \mathrm{C}$ for 12 and $24 \mathrm{~h}$ in $0.9 \%$ saline solution (goat [12]; sheep [15]), TCM 199 (goat [16]; sheep [17]) as well as in Braun-Collins or coconut water solution (goat [18]; sheep [23]). Therefore, in a medium rich or poor in nutrients, substantial degeneration was observed. 
The increase of cellular metabolism at the upper limit of temperature $\left(39^{\circ} \mathrm{C}\right)$ or close to it $(20$ ${ }^{\circ} \mathrm{C}$ ) and oxygen consumption could have caused depletion of intracellular energy sources, followed by consumption of the nutrients and oxygen available in the preservation medium, resulting in the higher degeneration rates found in these treatments. It is important to note that in all studies performed with the preservation of goat and sheep preantral follicles, a high rate of follicular degeneration was observed after storage at $39{ }^{\circ} \mathrm{C}$ for all incubation periods. On the other hand, the best results obtained in our study with preservation at $39{ }^{\circ} \mathrm{C}$ (normal metabolism) may be due to the short incubation period ( $2 \mathrm{~h}$ ). Smitz et al. [24] reported that preantral follicles are able to survive for a short interval under oxygen deficiency, and that glycolysis can sustain follicle viability for a limited interval.

In this study, TCM 199 was more effective than $0.9 \%$ saline solution in the preservation of sheep primordial follicles at $20^{\circ} \mathrm{C}$ for up to $24 \mathrm{~h}$. The primordial follicles had two nutrient sources, endogenous stores and nutrients from the preservation medium. Although these follicles were small, quiescent and had a low metabolic rate, they were also sensitive to adverse conditions in vitro, such as deficiences of oxygen and nutrients. We infer that at $4{ }^{\circ} \mathrm{C}$ (for all storage periods) and at $20^{\circ} \mathrm{C}$ (for up to $12 \mathrm{~h}$ ), sheep primordial follicles were able to survive on their own energetic sources, since both media had similar efficacy for follicle preservation. However, with increasing storage time and temperature, the composition of the medium became an important factor in the maintenance of follicular viability. The better results observed at higher temperatures and longer storage periods using TCM 199 were probably due to the nutrient composition of this medium, which is rich in inorganic salts, glucose, vitamins and amino acids [25]. This effect has already been demonstrated in the preservation of sheep preantral follicles (all classes taken together), where normal follicles were found after storage at $20^{\circ} \mathrm{C}$ in $0.9 \%$ saline solution and in TCM 199 for up to 4 and $12 \mathrm{~h}$, respectively, suggesting that the TCM 199 is an effective medium for preserving preantral follicles for longer periods [17]. In contrast to our results, Ferreira et al. [16] observed that preservation of goat preantral follicles in TCM 199 at $20{ }^{\circ} \mathrm{C}$ increased the percentage of degenerated follicles. However, comparisons between our study results and those of other studies are tenuous due to species differences, variation in types of follicles included in the final analysis and different experimental conditions.

Regarding the type of degeneration present in primordial follicles, histological analysis showed that in control as well as in fragments stored at 4 and $20^{\circ} \mathrm{C}$, the most common type of degeneration was Type 1 (only in the oocyte). Similar results were also observed with fresh (cow [1]; rat [26]; goat [14] and [27]; sheep [28]) and stored preantral follicles at $4{ }^{\circ} \mathrm{C}$ (cat [19]; goat [11], [16] and [18]; sheep [15]) as well as in cultured bovine preantral follicles [29] and 
[30]. According to Jorio et al. [28], degeneration of oocytes is the mode of atresia most frequently observed in preantral follicles. Silva et al. [11] reported that the oocyte of goat primordial follicles were more sensitive to degeneration than granulosa cells. Moreover, limited morphological evidence of biosynthetic activity in the granulosa cells of primordial follicles makes these cells less sensitive to degeneration [31]. In contrast, in treatments where the ovarian fragments were preserved at $39^{\circ} \mathrm{C}$, the most common type of degeneration was Type 2, where in addition to oocyte degeneration, the granulosa cells were disorganized and enlarged in volume. Similar results were observed by Silva et al. [18] in the preservation of goat preantral follicles in Braun-Collins and coconut water solutions at $39{ }^{\circ} \mathrm{C}$ for up to $24 \mathrm{~h}$. Granulosa cell pycnosis was commonly found in follicles preserved for more than $48 \mathrm{~h}$ [19] and may be used as the first histological indicator of atresia in antral follicles [32] and [33]. Barros et al. [34] suggested that the exposure of cells to a death signal, such as hypoxia, increased the influx of $\mathrm{Na}+$ to the cytosol, which activated the $\mathrm{Na} / \mathrm{K}$ ATPase, resulting in expenditure of ATP, cell swelling and consequently cellular degeneration. Another study has demonstrated that metabolic depletion in glial cells under chemical anoxia is followed by cell swelling [35].

In the present study, primordial follicles preserved in $0.9 \%$ saline solution at $4{ }^{\circ} \mathrm{C}$ for up to $24 \mathrm{~h}$ were ultrastructurally normal. In contrast, Carvalho et al. [12] reported that goat preantral follicles could be stored in $0.9 \%$ saline solution at $4{ }^{\circ} \mathrm{C}$ for only up to $12 \mathrm{~h}$. These results suggest that sheep primordial follicles are more resistant to preservation conditions than goat follicles. Primordial follicles stored in TCM 199 at $20^{\circ} \mathrm{C}$ for $24 \mathrm{~h}$ were histologically normal, but on ultrastructural analysis exhibited an ooplasm that was extremely vacated. Some authors have emphasized that normal sheep oocytes contain a great number of vacuoles [36] and [37], but in oocytes showing signs of degeneration, they become progressively more numerous [37]. Cytoplasmic vacuoles are also a characteristic sign of degeneration in granulosa [38] and cumulus cells [39] during degeneration in vivo and may represent endoplasmic reticulum swelling [37]. On the other hand, these vacuoles may be altered mitochondria, as observed by Fuku et al. [40] in cryopreserved bovine oocytes. The initial signs of damage to the mitochondria were probably induced by preservation. Silva et al. [11] reported that mitochondria with extensive swelling and disappearance of their cristae, as well as endoplasmic reticulum with increased volume, were the first signs of degeneration in goat preantral follicles. In contrast, the transmission electron microscopy analysis of the primordial follicles stored in TCM 199 at $20^{\circ} \mathrm{C}$ for $12 \mathrm{~h}$ revealed the ultrastructural integrity of these follicles.

In conclusion, sheep primordial follicles were stored successfully in $0.9 \%$ saline solution or in TCM 199 at $4{ }^{\circ} \mathrm{C}$ for up to $24 \mathrm{~h}$, at $20^{\circ} \mathrm{C}$ for up to $12 \mathrm{~h}$ and at $39{ }^{\circ} \mathrm{C}$ for up to $2 \mathrm{~h}$. These 
results should be beneficial to the culture of primordial follicles in vitro, which are performed at temperatures close to $39{ }^{\circ} \mathrm{C}$, due to the maintenance of follicular quality at $39{ }^{\circ} \mathrm{C}$ (physiological temperature) during ovary transportation to the laboratories (approximately 2 h).

\section{Acknowledgements}

This study was partially sponsored by CAPES, Brazil. The authors thank Dr. Vicente José de Figueirêdo Freitas (Laboratório de Fisiologia e Controle da Reprodução of State University of Ceará, Brazil) for the logistical support and Dr. Davide Rondina for the statistical analyses of data.

\section{References}

[1] Erickson GF. An analysis of follicle development and ovum maturation. Semin Reprod Endocrinol 1986;4:233-54.

[2] Carroll J, Whittingham DG, Wood MJ, Telfer E, Gosden RG. Extra-ovarian production of matures viable mouse oocytes from frozen primary follicles. J Reprod Fertil 1990;90:321-7.

[3] Figueiredo JR, Hulshof SCJ, van den Hurk R, Ectors FJ, Fontes RS, Nusgens B, et al. Development of a combined new mechanical and enzymatic method for isolation of intact preantral follicles from fetal, calf and adult bovine ovaries. Theriogenology 1993;40:789-99.

[4] Amorim CA, Rodrigues APR, Lucci CM, Figueiredo JR, Gonc, alves PBD. Effect of sectioning on the number of isolated ovine preantral follicles. Small Rumin Res 2000;37:269-77.

[5] Lucci CM, Rumpf R, Figueiredo JR, Ba'o SN. Zebu (Bos indicus) ovarian preantral follicles: morphological characterization and development of an efficient isolation method. Theriogenology 2002;57: 1467-83.

[6] Jewgenow K, Penfold LM, Meyer HHD, Wildt DE. Viability of small preantral ovarian follicles from domestic cats after cryoprotectant exposure and cryopreservation. J Reprod Fertil 1998;112:39-47.

[7] Liu HC, He Z, Rosenwaks Z. In vitro culture and in vitro maturation of mouse preantral follicles with recombinant gonadotropins. Fertil Steril 2002;77:373-83.

[8] Oktay K, Karlikaya GG, Aydin BA. Ovarian cryopreservation and transplantation: basic aspects. Mol Cell Endocr 2000;169:105-8.

[9] Eppig JA. Comparison between oocyte growth in co-culture with granulosa cells and oocytes with granulosa cell-oocyte junctional contact maintained in vitro. J Exp Zool 1979;209:345-53.

[10] Eppig JA. Growth and development of mammalian oocytes in vitro. Arch Pathol Lab Med 1992;116: 379-82. 
[11] Silva JRV, Ba'o SN, Lucci CM, Carvalho FCA, Andrade ER, Ferreira MAL, et al. Morphological and ultrastructural changes occuring during degeneration of goat preantral follicles preserved in vitro. Anim Reprod Sci 2001;66:209-23.

[12] Carvalho FCA, Lucci CM, Silva JRV, Andrade ER, Ba'o SN, Figueiredo JR. Effect of BraunCollins and saline solutions at different temperatures and incubation times on the quality of goat preantral follicles preserved in situ. Anim Reprod Sci 2001;66:195-208.

[13] Solano R, Armas R, Pupo CA, Castro FO. Short term preservation of intrafollicular oocytes at 4 8C. Theriogenology 1994;41:299.

[14] Lucci CM, Amorim CA, Ba'o SN, Figueiredo JR, Rodrigues APR, Silva JR, et al. Effect of the interval of serial sections of ovarian in the tissue chopper on the number of isolated caprine preantral follicles. Anim Reprod Sci 1999;56:39-49.

[15] Andrade ER, Rodrigues APR, Amorim CA, Carvalho FCA, Dode MAN, Figueiredo JR. Short term maintenance of sheep preantral follicles in situ in $0.9 \%$ saline and Braun-Collins solution. Small Rumin Res 2001;41:141-9.

[16] Ferreira MAL, Brasil AF, Silva JRV, Andrade ER, Rodrigues APR, Figueiredo JR. Effects of storage time and temperature on atresia of goat ovarian preantral follicles held in M199 with or without indole-3-acetic acid supplementation. Theriogenology 2001;55:1607-17.

[17] Andrade ER, Amorim CA, Costa SHF, Ferreira MAL, Rodrigues APR, Dode MAN, et al. Preliminary study of short-term preservation of ovine ovarian tissue containing preantral follicles in saline solution or TCM 199. Vet Rec 2002;151:452-3.

[18] Silva JRV, Lucci CM, Carvalho FCA, Ba'o SN, Costa SHF, Santos RR, et al. Effect of coconut water and Braun-Collins solutions at different temperatures and incubation times on the morphology of goat preantral follicles preserved in vitro. Theriogenology 2000;54:809-22.

[19] Wood TC, Montali RJ, Wildt DE. Follicle-oocyte atresia and temporal taphonomy in coldstored domestic cat ovaries. Mol Reprod Dev 1997;46:190-200.

[20] Roy SK, Treacy BJ. Isolation and long-term culture of human preantral follicles. Fertil Steril 1993;59: 783-90.

[21] Pickering SJ, Braude PR, Johnson MH, Cant A, Currie J. Transient cooling to room temperature can cause irreversible disruption of the meiotic spindle in the human oocyte. Fertil Steril 1990;54:102-7.

[22] Matson BA, Albertini DF. Oogenesis: chromatin and microtubule dynamics during meiotic prophase. Mol Reprod Dev 1990;25:374-83.

[23] Andrade ER, Amorim CA, Matos MHT, Rodrigues APR, Silva JRV, Dode MAN, et al. Evaluation of saline and coconut water solutions in the preservation of sheep preantral follicles in situ. Small Rumin Res 2002;43:235-43.

[24] Smitz J, Cortvrindt R, Van Steirteghem AC. Normal oxygen atmosphere is essential for the solitary longterm culture of early preantral mouse follicles. Mol Reprod Dev 1996;45:466-75.

[25] Migliorisi G, Folkes E, Pawlowski N. Human endothelial cells. Am J Pathol 1987;127:157. 
[26] Hirshfield AN. Size frequency analysis of atresia in cycling rats. Biol Reprod 1988;38:11818.

[27] Bezerra MB, Rondina D, Lima AKF, Oliveira LC, Cecchi R, Lucci CM, et al. Aspectos quantitativos e qualitativos da foliculoge^nese na fase pre'-natal na espe'cie caprina. Cie^ncia Anim 1998;8:47-56.

[28] Jorio A, Mariana JC, Lahlou-Kassi A. Development of the population of ovarian follicles during the prepubertal period in D'man and Timahdite sheep. Anim Reprod Sci 1991;26:23950.

[29] Figueiredo JR, Hulshof SCJ, van den Hurk R, Nusgens B, Bevers MM, Ectors FJ, et al. Preservation of oocyte and granulosa cell morphology in bovine preantral follicles cultured in vitro. Theriogenology 1994;41:1333-46.

[30] Braw-Tal R, Yossefi S. Studies in vivo and in vitro on the initiation of follicle growth in the bovine ovary. J Reprod Fertil 1997;109:165-71.

[31] Hirshfield AN. Development of follicles in the mammalian ovary. Int Rev Cytol 1991;124:43-101.

[32] Grimes RW, Matton P, Ireland JJ. A comparison of histological and non histological indices of atresia and follicular function. Biol Reprod 1987;37:82-8.

[33] Blodin P, Dufour M, Sirard MA. Analysis of atresia in bovine follicles using different methods: flow citometry, enzime-linked immunosorbent assay, and classic histology. Biol Reprod 1996;54:631-7.

[34] Barros LF, Hermosilla T, Castro J. Necrotic volume increase and the early physiology of necrosis. Comp Biochem Physiol 2001;130:401-9.

[35] Jurkowitz-Alexander MS, Altschuld RA, Hohl CM, et al. Cell swelling, blebbing, and death are dependent on ATP depletion and independent of calcium during chemical hypoxia in a glial cell line (ROC-1). J Neurochem 1992;59:344-52.

[36] Cran DG, Moor RM, Hay MF. Fine structure of the sheep oocyte during antral follicles development. J Reprod Fertil 1980;59:125-32.

[37] Tassel R, Kennedy JP. Early follicular development and atretic changes in the ovary of the lamb-fine structure and histochemistry. Aust J Biol Sci 1980;33:675-87.

[38] Hay MF, Cran DG, Moor RM. Structural changes occuring during atresia in sheep ovarian follicles. Cell Tissue Res 1976;169:515-29.

[39] Assey RJ, Hyttel P, Kanuya N. Oocyte structure in dominant and subordinate follicles in zebu cattle (Bosindicus). Anat Embryol 1994;190:461-8.

[40] Fuku E, Xia L, Downey BR. Ultrastructural changes in bovine oocytes cryopreserved by vitrification. Cryobiology 1995;32:139-56. 